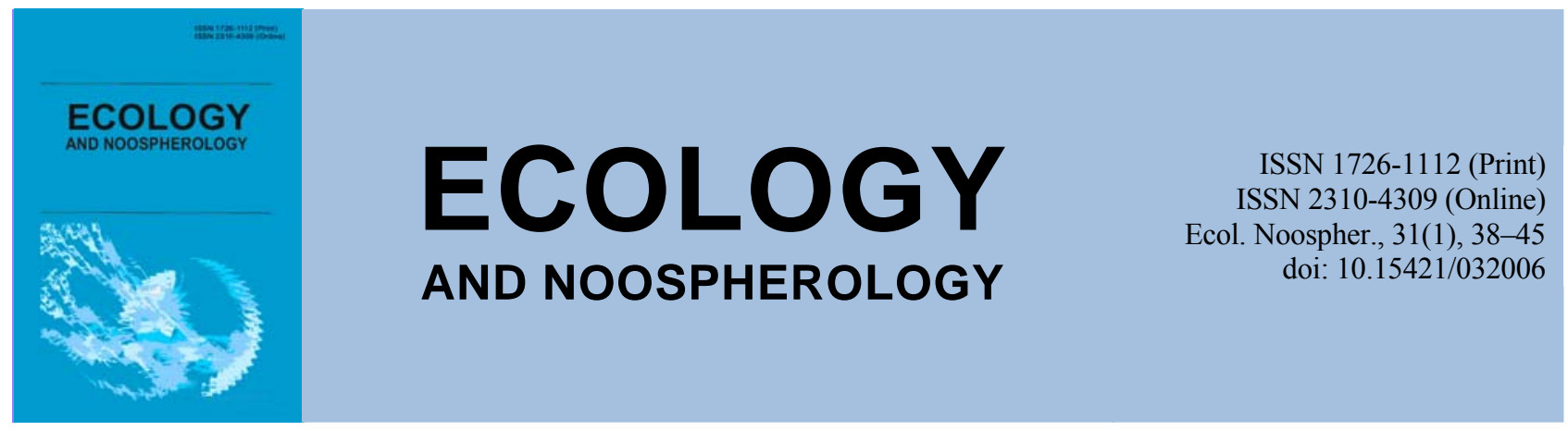

\title{
Influence of seasonal climatic factors on the dynamics of birds interactions with linden consortia
}

\author{
O. L. Ponomarenko
}

Oles Honchar Dnipro National University, Dnipro, Ukraine

Article info

Received 04.03.2020

Received in revised form

10.03.2020

Accepted 18.03.2020

Oles Honchar Dnipro

National University

Gagarin Ave., 72, Dnipro,

49010, Ukraine.

Tel.: +38-066-439-05-72

E-mail:aponomar@ua.fm

\begin{abstract}
Ponomarenko, O. L. (2020). Influence of seasonal climatic factors on the dynamics of birds interactions with linden consortia. Ecology and Noospherology, 31(1), 38-45. doi:10.15421/032006
\end{abstract}

The article is devoted to the bird communities in individual linden consortia (Tilia cordata Mill.) of the linden-ash oak forests. This work material was collected during different seasons of the 20092017 years in a linden-ash oak grove on the test plot No. 209 of the ecological profile of the NSC «Bel'gard Prisamar'e International Biospheric stationary», Novomoskovsk district, Dnepropetrovsk region. The individual consortia of 145 examples of three age conditions oak trees (virgins - virg, young generative $-\mathrm{gl}$, mature and old generative individuals $-\mathrm{g} 2-\mathrm{g} 3$ ) has been investigated. Studies have shown that birds are actively involved in consortia of linden for most of the year. Meroconsortia of linden generative organs are attractive to birds during the growing season and in the cold season. In summer, the consortia of linden in terms of species composition of birds is inferior to the consortia of oak about 2 times. The same trend is observed in DTB and DMB. Only 2 species of birds participate in the consortia of the virgin linden. The consortia of young generative linden consists of only 4 species of birds, but DTB increases almost 30 times. The consortia of mature and old generative linden acquires a sufficient species composition - 14 species of birds. Interactions of birds with virginal linden are stochastic in autumn. Only 2 species of birds participate in the consortia of virgin linden in autumn. The consortia of young generative linden consists of 5 species (more than in summer). The old generative linden has a depression of consortia interactions of birds. Their volume is reduced by half compared to summer. Specialized consumers of linden nuts remain in the consortia of old generative linden mainly. Birds have very low DTB and DMB rates in consortia of all linden age groups in winter. Instead, the species composition of birds increases in the consortia of generative groups of linden in winter. The system of consortia interactions of birds is not intensive, but stable on the linden tree in winter. The volume of interactions of birds with a linden tree essentially increases in the spring. This trend is typical for trees with a dense crown. The number of consort birds is higher than in summer in consortia of virgin and young generative linden. DTB is five times higher in virgin linden than in summer. The participation of birds in the consortia of young generative linden is also greater than in summer. We believe that this is due to the fact that linden begins to grow earlier than other trees in the upper tier. The old generative linden is one of the main feeding grounds for birds in the spring. Linden, like common oak, is much more interesting for birds in spring and summer in contrast to field maple and ash. Linden first supports the system of trophic connections, and then topical in most seasons of the year. Linden forms stable groups of birds at a young generative stage during the year. Linden creates an environment for birds to live in the middle tier and complements the field maple.

Keywords: birds; linden; consortia; consortia interactions; dynamics during the year

\section{Вплив сезонних кліматичних факторів на динаміку консортивних зв'язків птахів з липою серцелистою}

\author{
О. Л. Пономаренко
}

Дніпровський національний університет імені Олеся Гончара, Дніпро, Україна 
Стаття присвячена угрупованням птахів в індивідуальних консорціях асектатора липово-ясеневих дібров - липи серцелистої (Tilia cordata Mill.). Матеріал даної роботи збирався у різні пори року 2009-2017 рр. у липово-ясеневій діброві із зірочником на пробній площі № 209 екологічного профілю ННЦ «Присамарський міжнародний біосферний стаціонар ім. О. Л. Бельгарда», Новомосковський район, Дніпропетровська область. Дослідженням було піддано індивідуальні консорції 145 екземплярів липи серцелистої трьох вікових станів (віргінільні особини - virg, молоді генеративні - gl, зрілі та старі генеративні особини - g2-g3). У результаті досліджень було виявлено, що птахи беруть активну участь в консорціях липи серцелистої протягом більшої частини року. Мероконсорції генеративних органів липи привабливі для птахів у вегетативний період і в холодну пору року. Влітку консорція липи за видовим складом птахів поступається консорції дуба приблизно в 2 рази. Така ж тенденція помітна в показниках DTB та DMB. Лише 2 види птахів беруть участь в консорції віргінільної липи. Консорція молодої генеративної липи має в своєму складі всього лише 4 види птахів, але DTB збільшується майже в 30 разів. Консорція зрілої та старої генеративної липи набуває достатнього видового складу - 14 видів птахів. Взаємодії птахів з віргінільною липою мають стохастичний характер восени. Лише 2 види птахів беруть участь в консорції віргінільної липи восени. Консорція молодої генеративної липи має в своєму складі 5 видів (більше, ніж улітку). Стара генеративна липа має депресію консортивних взаємодій птахів. Їх обсяг зменшується в два рази порівняно $з$ літом. Спеціалізовані споживачі горішків липи залишаються у складі консорції старої генеративної липи переважно. Птахи мають дуже малі показники DTB та DMB в консорціях усіх вікових груп липи взимку. Натомість видовий склад птахів збільшується в консорції генеративних груп липи взимку. Система консортивних взаємодій птахів не інтенсивна, але стабільна на липі взимку. Обсяг взаємодій птахів з липою суттєво зростає весною. Ця тенденція властива для деревних порід 3 щільною кроною. Кількість птахів-консортів більша, ніж літом у консорціях віргінільної та молодої генеративної липи. DTB більший в п'ять разів у віргінільної липи, ніж улітку. Обсяг участі птахів у консорції молодої генеративної липи також більший, ніж улітку. Ми вважаємо, що це пов'язано з тим, що липа починає вегетацію раніше, ніж інші дерева верхнього ярусу. Стара генеративна липа $\epsilon$ одним з основних місць живлення птахів весною. Липа, як звичайний дуб, значно цікавіша для птахів у весняно-літній період, на відміну від польового клена та ясена. Липа перш за все підтримує систему трофічних зв'язків, а потім топічних у більшості сезонів року. Липа утворює стабільні угруповання птахів на молодій генеративній стадії протягом року. Липа створює середовище для мешкання птахів у середньому ярусі та доповнює клен польовий.

Ключові слова: птахи; липа серцелиста; консорція; консортивні взаємодії; динаміка протягом року

\section{Встуі}

Дослідження консорцій почалися вже досить давно - в середині 20-го сторіччя (Beklemishev, 1951; Ramenskiy, 1952; Mazing, 1966), але цей напрям в біогеоценології до цього часу є актуальним з причини складності об'єкта досліджень - самих консорцій. До цього часу публікуються наукові праці, які присвячені класифікації консорцій та їх сутності, як екологічного явища, але 3 нашої точки зору ці роботи мають радше теоретичний характер i не дуже актуальні 3 точки зору охорони конкретних природних об'єктів та відновлення реальних екосистем. Значно більш цінними $є$ дослідження, які дають інформацію про організацію консорцій реальних деревних порід, які утворюють деревостани в певному регіоні i дають фактичне та теоретичне підгрунтя для створення штучних екосистем та відновлення природних. 3 нашої точки зору саме до таких і належить дане дослідження.

Обсяг досліджень участі птахів у функціонуванні автотрофних та гетеротрофних консорцій вже достатньо великий (Chaplygina et al., 2016a, 2016b; Ponomarenko, 2005; Ponomarenko, Shul'man, 2019; Ponomarenko, Reva, 2019; Tryfanova et al., 2015; Yuzyk, Chaplygina, 2015). В цих наукових працях висвітлюються питання розвитку системи консортивних зв'язків птахів протягом онтогенезу ядра консорції, функціональний склад птахів-консортів, їх чисельність та просторовий розподіл. Також в останніх працях розглянуто питання міжсезонної динаміки консортивних зв'язків птахів. Ці роботи стосуються дуба звичайного та клена польового, але подібних праць по консорціях липи серцелистої не було. Ця стаття присвячена аналізу динаміки участі птахів в індивідуальних консорціях липи серцелистої трьох вікових груп протягом року.

\section{Матеріали та методи досліджень}

В основу методологічного підходу досліджень покладено вчення В. М. Сукачова (Sukachev, 1972) про біогеценоз, типологію штучних i природних лісів степової зони О. Л. Бельгарда (Belgard, 1960, 1971), вчення В. І. Беклемішева (Beklemishev, 1951), Л. Г. Раменського (Ramenskiy, 1952), В. В. Мазинга (Mazing, 1966) про консорції.
Матеріал даної роботи збирався в різні пори року 2009-2017 pр. у липово-ясеневій діброві із зірочником (пробна площа № 209 екологічного профілю ННЦ «Присамарський міжнародний біосферний стаціонар ім. О. Л. Бельгарда»). Для дослідження консортивних зв'язків птахів за об'єкти було обрано індивідуальні консорції липи серцелистої (Tilia cordata Mill.). Дослідженням було піддано індивідуальні консорції 145 екземплярів дуба звичайного трьох вікових станів (віргінільні особини - virg, молоді генеративні - gl, зрілі та старі генеративні особини - g2-g3). Віковий стан детермінантів консорції визначався за Смирновою зі співавторами (Smirnova et al., 1976). За основу для збору матеріалу 3 активності птахів була обрана методика, запропонована О. Л. Пономаренком (Ponomarenko, 2017). Матеріал збирався по чотирьох сезонах: навесні, влітку, восени та взимку.

Липа $\epsilon$ специфічною щільнокронною породою, яка трапляється у складі липово-ясеневих дібров Присамар'я. Ця порода вирізняється густою затемненою кроною (Tkachenko, 1955), завдяки якій вона може перешкоджати зростанню трав'янистого ярусу під нею. Липа у перші роки зростання вирізняється повільними його темпами і тому не утворює значної щільності у підліску. Насіннєвий підріст липи рідко буває чисельним, на відміну від кленів або ясена (Tkachenko, 1955), i липа може активно відновлюватися вегетативно. У процесі онтогенезу темпи росту липи зростають i вона бере активну участь у формуванні другого ярусу, у деяких випадках навіть першого. Е. М. Ткаченко (Tkachenko, 1955) вважає цю деревну породу ентомофільною, що може впливати на формування угруповань птахів.

В умовах липово-ясеневих дібров заплави трапляння липи обмежено особливостями іiі екології. Вона виростає лише на приозерних підвищеннях і на ділянках, де грунт трохи полегшений наносами піщанистої фракції (Belgard, 1971; Grigorenko, Lyindya, 1977). Тому вона виступає в липово-ясеневих дібровах як асектатор. Як правило, липа разом із кленами і зрідка грушею утворює другий ярус насаджень, а при наявності пенькових проростків може входити до складу підліску (Belgard, 1971; Grigorenko, Lyindya, 1977). Особливістю липи як породи є також те, що в першій половині літа вона формує тимчасові, але 
досить своєрідні мероконсорції генеративних органів, що, у свою чергу, за рахунок розширення складу організмів першого концентра, залучає птахів.

Висота досліджуваних лип коливалася в межах 15-23 м у зрілому та старому генеративному стані $(g 2-g 3), 13-16$ м у молодому генеративному стані $(g l)$, та 2-6 м - у віргінільному стані. Розмах крони коливався у межах 6-8 м, 4-6 м, 2-3,5 м відповідно.

\section{Результати та їх обговорення}

Липа серцелиста протягом року підтримує досить активну систему зв'язків 3 птахами, незважаючи на несприятливі умови у холодні пори року. Цьому значною мірою допомагає формування мероконсорцій генеративних органів. Також липа, як і клен польовий, вражається омелою (Viscum album L.). У зимовий період наявність цієї паразитичної рослини приваблює птахів у консорцію липи.

Осінній період відзначається у функціонуванні консорції віргінільної липи ще більшою депресією порівняно з літом. Загальні показники активності птахів мають дуже низький рівень, який свідчить про відсутність систематичності у зв'язках. Загальний бюджет часу $\epsilon$ найменшим серед аналогічних показників інших порід (табл. 1). Більшу його частину складають топічні зв'язки (див. табл. 1). Бюджет маси також дуже низький і свідчить про відсутність стабільності зв'язків (див. табл. 1). Усього у складі консорції зафіксовано 2 види птахів.

Трофічна складова має 2 види - велику синицю та вільшанку (рис. 1, A1, A2). Домінантом є перший вид, субдомінантом - другий. Обидва види виявили активність усього лише на $40 \%$ досліджуваних особин липи і $€$ типовими для діброви в осінній період.

Топічна складова також має ті самі 2 види (рис. 1, $A 3$ ). Домінантом, як і у трофічній складовій, $є$ велика синиця. Єдиним видом активності, який було відстежено, $\epsilon$ спостереження. Ця активність не виявлялася на всіх досліджуваних екземплярах. Таким чином, впорядкована система консортивних зв'язків птахів 3 віргінільною липою восени відсутня.

Консортивне угруповання молодої генеративної липи восени характеризується підвищенням стабільності порівняно з віргінільною липою. Усього у складі консорції зафіксовано 5 видів птахів. 3 іншого боку, загальні показники досить невисокі. Більшу частину загального DTB складають трофічні зв'язки. Бюджет маси дуже низький, що є наслідком значного зменшення кількості птахів у діброві восени (див. табл. 1).

Таблиця 1

Характеристика консортивних зв'язків птахів у консорціях липи серцелистої

\begin{tabular}{|c|c|c|c|c|}
\hline \multirow{2}{*}{ Сезон } & \multirow{2}{*}{ Параметри системи зв'язків } & \multicolumn{3}{|c|}{ Віковий стан } \\
\hline & & $v$ & $g 1$ & $g 2-g 3$ \\
\hline \multirow{5}{*}{ Літо } & Бюджет часу (DTB), сек & $26,5+3,15$ & $775,01+38,17$ & $931,33+95,37$ \\
\hline & Бюджет маси (DMB), г & $11,32+3,15$ & $93,06+8,42$ & $217,11+45,12$ \\
\hline & Кількість видів консортів & 2 & 4 & $1 \overline{4}$ \\
\hline & Доля трофічних зв'язків, \% & 15,1 & 66,8 & 61,4 \\
\hline & Доля топічних зв'язків, \% & 84,9 & 33,2 & 38,6 \\
\hline \multirow{5}{*}{ Осінь } & Бюджет часу (DTB), сек & $4,15 \pm 2,73$ & $157,36+41,09$ & $531,18+111,57$ \\
\hline & Бюджет маси (DMB), г & $0,56 \pm 0,32$ & $11,28 \pm 4,25$ & $78,09 \pm 21,13$ \\
\hline & Кількість видів консортів & 2 & 5 & 7 \\
\hline & Доля трофічних зв'язків, \% & 31,3 & 89,6 & 71,7 \\
\hline & Доля топічних зв'язків, \% & 68,7 & 10,4 & 28,3 \\
\hline \multirow{5}{*}{ Зима } & Бюджет часу (DTB), сек & $0,56 \pm 0,42$ & $2,46 \pm 1,51$ & $11,66+5,12$ \\
\hline & Бюджет маси (DMB), г & $\overline{0}$ & $2,17 \pm 0,39$ & $2,01 \pm 1,56$ \\
\hline & Кількість видів консортів & 2 & $\overline{8}$ & $\overline{9}$ \\
\hline & Доля трофічних зв'язків, \% & 0 & 47,6 & 47,5 \\
\hline & Доля топічних зв'язків, \% & 100 & 52,4 & 52,5 \\
\hline \multirow{5}{*}{ Весна } & Бюджет часу (DTB), сек & $130,25 \pm 28,11$ & $324,00 \pm 39,81$ & $776,57 \pm 112,32$ \\
\hline & Бюджет маси (DMB), г & $29,55+8,32$ & $66,19 \pm 10,72$ & $99,27 \pm 11,34$ \\
\hline & Кількість видів консортів & 4 & 8 & $\overline{13}$ \\
\hline & Доля трофічних зв'язків, \% & 42,1 & 59,6 & 68,6 \\
\hline & Доля топічних зв'язків, \% & 57,9 & 40,1 & 31,4 \\
\hline
\end{tabular}

Трофічна складова утворена активністю 5 видів птахівконсортів (рис. 1, Б1, Б2). Домінант - велика синиця, субдомінанти - повзик та вільшанка. Співвідношення по концентрах складає: I - 4,00 \%, II - 86,92 \%, III - 9,08 \% від DTB трофічних зв'язків. Активність у першому концентрі забезпечується виключно живленням повзика горішками липи, у третьому - в основному живленням великої синиці та вільшанки. Характерні риси: участь у консорції виключно осіннього корінного орнітонаселення діброви, низький рівень участі повзика у мероконсорціях генеративних органів молодої генеративної липи, що свідчить про нестабільність даної мероконсорції.

Топічна складова консорції липи у віці $g 1$ має активність 4 видів (рис. 1, Б3). Усі види одночасно $є$ i трофоконсортами, це $\epsilon$ наслідком впливу трофічної складової. Домінантом є велика синиця, субдомінантом вільшанка. У консорції виявлено 2 види топічних зв'язків птахів - спостереження i відпочинок. Домінуючим $\epsilon$ перший. Обидва їх види виявила тільки велика синиця. Це свідчить про обмеженість використання липи як топічного субстрату птахами. Таким чином, восени консорція молодої генеративної липи відчуває більш потужний процес депресії, ніж інші породи.

Консортивне угруповання зрілої та старої генеративної липи восени $\epsilon$ одним 3 найменш розвинутих серед деревних порід цієї вікової категорії. Усього в консорції зафіксовано 7 видів птахів-консортів - не набагато більше, ніж у молодої генеративної липи. Більшу частину загального бюджету часу складають трофічні зв'язки (див. табл. 1). Бюджет маси має невисокий показник.

Трофічна складова характеризується участю 7 видів птахів (рис. 1, B1, B2). Домінантом у цій частині зв'язків $\epsilon$ велика синиця. Субдомінантами - повзик, вільшанка, звичайний дятел. Усі ці види є характерними для діброви восени. Співвідношення по концентрах складає: I - 10,01\%, II $-80,25 \%$, III $-9,74 \%$ від DTВ трофічних зв'язків. Активність у першому концентрі значно зростає завдяки досить активному живленню повзика горішками липи, у 

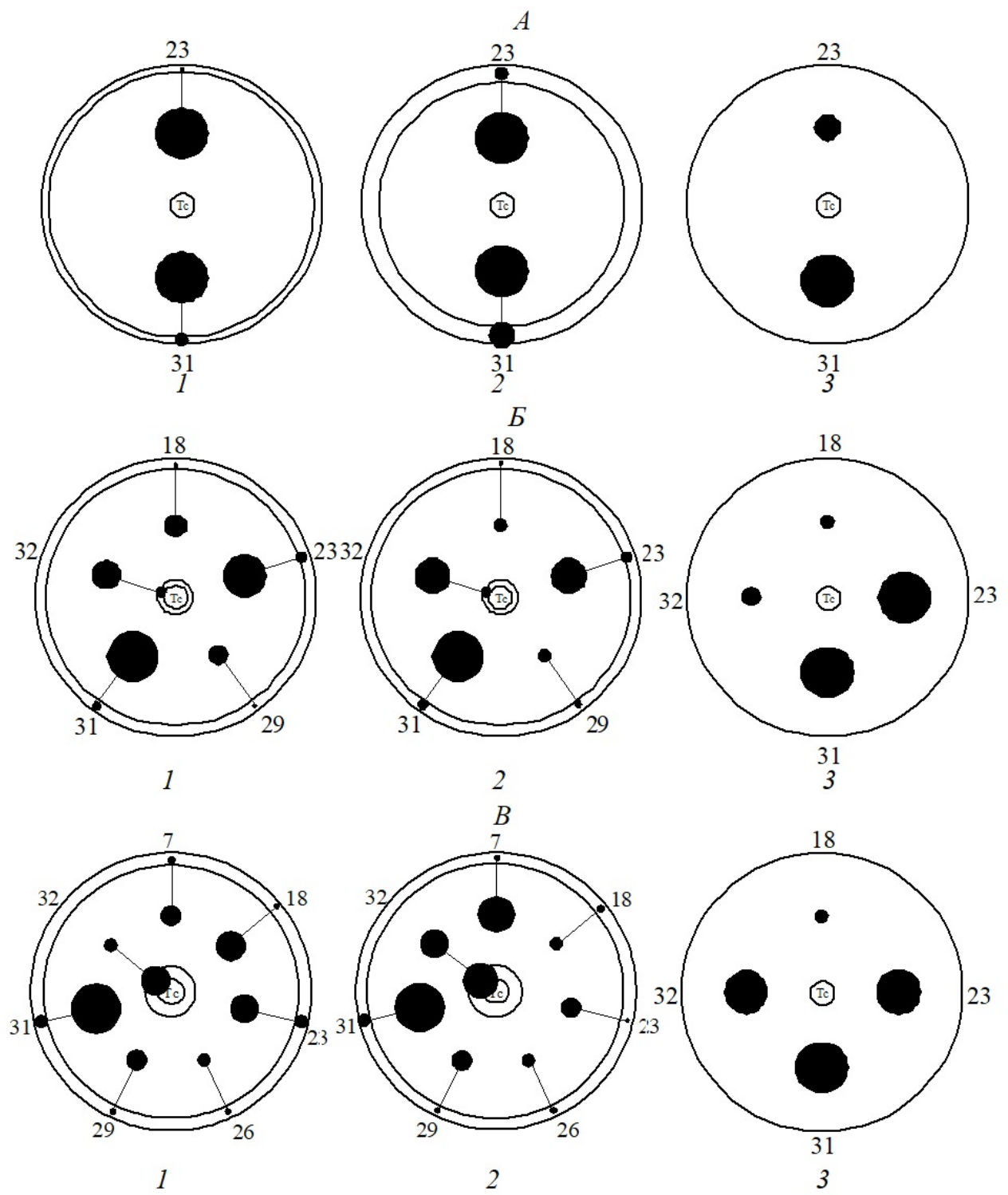

Рис. 1. Схеми консортивних зв'язків птахів з липою серцелистою за бюджетами часу та маси на один екземпляр автотрофа в осінній період:

А - віргінільним $-v$; Б - молодим генеративним $-g 1$; В - зрілим та старим генеративним $-g 2-g 3 ; 1-$ трофічних зв'язків за бюджетом часу; 2 - трофічних зв'язків за бюджетом маси; 3 - топічних зв'язків за бюджетом часу.

Номерами на схемах позначено консортивні зв'язки видів: 1 - Accipiter gentilis; 2 - Buteo buteo; 3 - Cuculus canorus; 4 -Strix aluco; 5 -Jynx torquilla; 6 - Picus canus; 7 -Dendrocopos major; 8 -Dendrocopos medius; 9 -Dendrocopos mino;

10 - Anthus trivialis; 11 - Oriolus oriolus; 12 - Garrulus glandarius; 13 - Corvus cornix; 14 -Bombycilla garrulus;

15 - Sylvia atricapilla; 16 - Sylvia curruca; 17 - Sylvia communis; 18 - Phylloscopus collybita; 19 - Phylloscopus sibilatrix;

20 - Muscicapa striata; 21 - Ficedula hypoleuca; 22 - Ficedula albicollis; 23 - Erithacus rubecula; 24 - Luscinia luscinia;

25 - Turdus merula; 26 - Turdus philomelos; 27 - Turdus viscivorus; 28 -Aegithalos caudatus; 29 - Parus caeruleus;

30 - Parus palustris; 31 - Parus major; 32 - Sitta europaea; 33 - Certhia familiaris; 34 - Passer montanus; 35 - Fringilla coelebs; 36 - Chloris chloris; 37 - Carduelis carduelis; 38 - Pyrrhula pyrrhula; 39 - Coccothraustes coccothraustes; 40 - Emberiza citrinella.

третьому концентрі беруть участь майже усі види. Це пов'язано 3 тим, що популяції фітофагів швидше зменшують свою чисельність восени, а доля комах-хижаків у спектрі живлення птахів восени зростає. Урізноманітнює систему зв'язків також участь звичайного дятла, який живиться шкідниками деревини липи.

Топічна складова представлена активністю 4 видів птахів (рис. 1, B3). Домінантом $є$ велика синиця, субдомінанти - вільшанка та повзик. У складі консорції зафіксовано 3 види топічних зв'язків: спостереження, спів, відпочинок. Це свідчить про достатньо різноманітне, як на осінній період, використання топічного субстрату липи птахами. Таким чином, угруповання зрілої та старої генеративної липи має нечисленне, але стабільне угруповання, яке утворюється корінним орнітонаселенням діброви.
У зимовий період, коли головною статтею бюджету часу птахів $є$ живлення, на відміну від інших порід липа здебільшого виконує роль топічного субстрату. Тому консортивні угруповання цієї деревної породи мають мало інтенсивну, але досить стабільну систему зв'язків птахів.

Консортивне угруповання птахів віргінільної липи взимку взагалі не виявляс трофічних зв'язків, що свідчить про відсутність значних трофічних ресурсів. Топічні зв'язки складають $100 \%$ від загального бюджету часу (див. табл. 1). За даними спостережень, близько 60 \% досліджуваних лип не відвідувалися птахами взагалі. У складі консорції зафіксовано 2 види - велика синиця і болотяна гайчка (рис. 2, A3). Домінантом $\epsilon$ велика синиця, активність гаїчки сягає рівня субдомінанта. Зафіксовано 1 вид зв'язку - спостереження. Усі показники свідчать про відсутність впорядкованої системи зв'язків птахів з віргінільною липою взимку. 

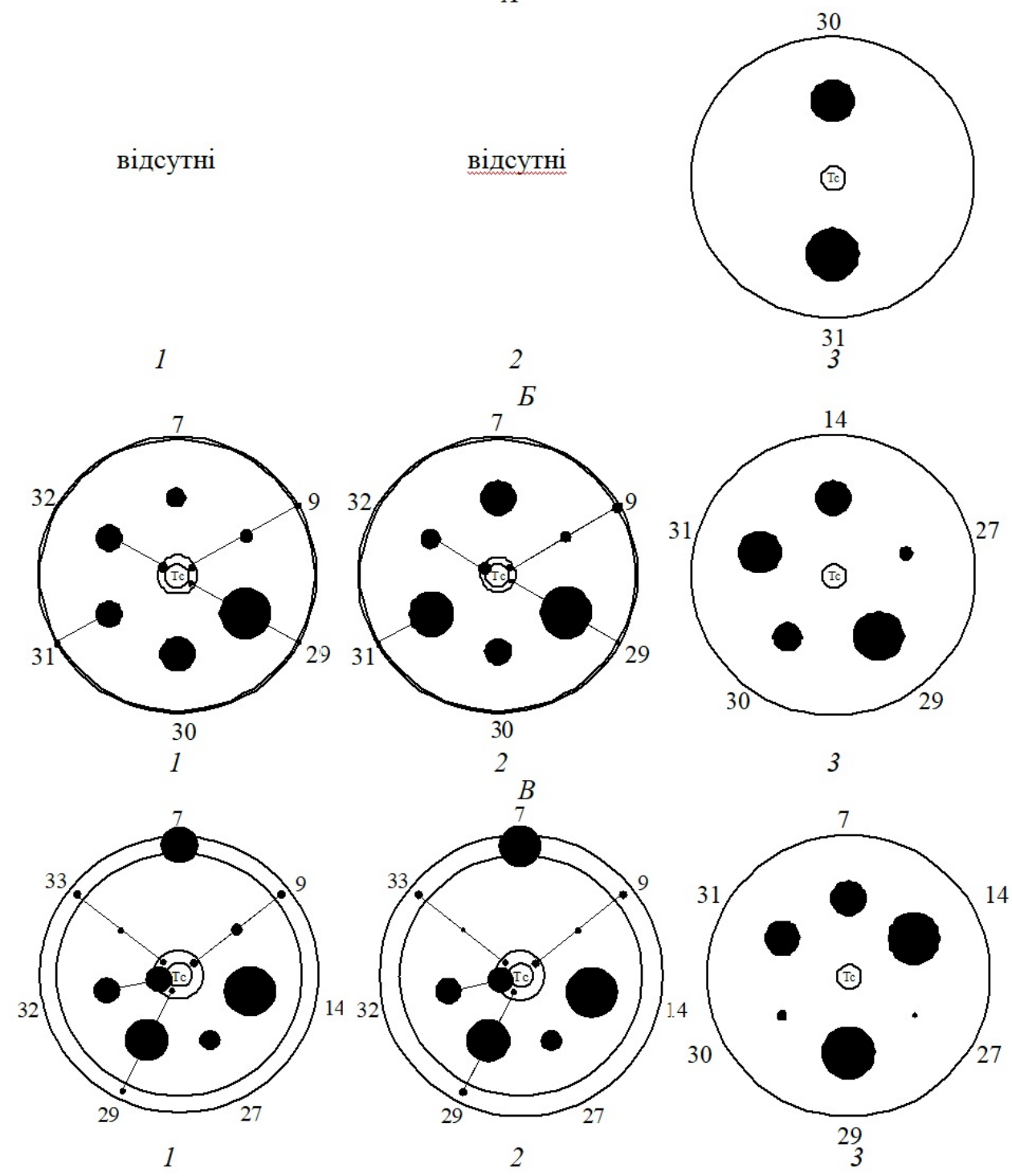

Рис. 2. Схеми консортивних зв'язків птахів з липою серцелистою за бюджетами часу та маси на один екземпляр автотрофа в зимовий період:

А - віргінільним - $v$; Б - молодим генеративним $-g 1$; В - зрілим та старим генеративним - g2-g3; 1 - трофічних зв'язків за бюджетом часу; 2 - трофічних зв'язків за бюджетом маси; 3 - топічних зв'язків за бюджетом часу.

Номерами на схемах позначено консортивні зв'язки видів: 1 -Accipiter gentilis; 2 - Buteo buteo; 3 - Cuculus canorus; 4 - Strix aluco; 5 - Jynx torquilla; 6 - Picus canus; 7 - Dendrocopos major; 8 -Dendrocopos medius; 9 - Dendrocopos mino;

10 - Anthus trivialis; 11 - Oriolus oriolus; 12 - Garrulus glandarius; 13 - Corvus cornix; 14 - Bombycilla garrulus;

15 - Sylvia atricapilla; 16 - Sylvia curruca; 17 - Sylvia communis; 18 - Phylloscopus collybita; 19 - Phylloscopus sibilatrix;

20 - Muscicapa striata; 21 - Ficedula hypoleuca; 22 - Ficedula albicollis; 23 -Erithacus rubecula; 24 - Luscinia luscinia;

25 - Turdus merula; 26 - Turdus philomelos; 27 - Turdus viscivorus; 28 -Aegithalos caudatus; 29 - Parus caeruleus;

30 - Parus palustris; 31 - Parus major; 32 - Sitta europaea; 33 - Certhia familiaris; 34 - Passer montanus; 35 - Fringilla coelebs; 36 - Chloris chloris; 37 -Carduelis carduelis; 38 - Pyrrhula pyrrhula;

39 - Coccothraustes coccothraustes; 40 - Emberiza citrinella.

Консортивне угруповання молодої генеративної липи взимку має найнижчий загальний бюджет часу на один екземпляр автотрофа (див. табл. 1). Бюджет маси також має дуже низький показник. Усього у складі консорції виялено 8 видів птахів (див. табл. 1).

Трофічна складова системи зв'язків угруповання характеризується участю 6 видів птахів (рис. 2, Б1, Б2). Домінантом у цій частині консортивних зв'язків $\epsilon$ блакитна синиця, субдомінантами - повзик, звичайний дятел, болотяна гаїчка, велика синиця. Наявність великої кількості субдомінантів при невеликій загальній кількості видів свідчить про неспеціалізованість системи трофічних зв'язків. Співвідношення по концентрах складає: I - 6,52 \%, II - 91,30\%, III - 2,18 \% від DTВ трофічних зв'язків. Активність у першому концентрі забезпечується перш за все вживанням повзиком у невеликих кількостях горішків липи, у третьому - активністю блакитної та великої синиць.

Топічна складова нараховує активність 5 видів птахів (рис. 2, Б3). Домінантом у цій частині є також блакитна синиця, субдомінантами - велика синиця і омелюх. У складі консорції виявлено 2 види зв'язків: спостереження та відпочинок. Обидва види активності виявила тільки блакитна синиця. Топічна складова загалом відчуває вплив трофічної - види-трофоконсорти також і відпочивають на липі. Усе це свідчить про досить просту структуру топічних зв'язків птахів.

Консортивне угруповання птахів зрілої та старої генеративної липи взимку нараховує 9 видів птахівконсортів. Загальний бюджет часу на один екземпляр автотрофа складає досить малу навіть для зимового часу величину (див. табл. 1). За цим показником липа 
поступається усім іншим деревним породам. Більшу частину бюджету складають топічні зв'язки (див. табл. 1).

Трофічна складова характеризується участю 7 видів птахів (рис. 2, B1, B2). Домінантом серед трофоконсортів $\epsilon$ омелюх, субдомінантами - блакитна синиця, повзик, великий дятел. Дольова участь інших видів коливається в межах від 1,47 до 7,48 \% від бюджетів часу та маси. Співвідношення по концентрах складає: I - 10,84 \%, II $75,12 \%$, III - 14,04 \% від DTВ трофічних зв'язків. Активність у першому концентрі забезпечується живленням повзика горішками липи, у третьому активним живленням звичайного та малого дятлів деревними видами мурах. Незважаючи на свою досить складну та багату структуру, це угруповання нестійке, оскільки дуже велику частку займають тимчасові спеціалізовані трофічні зв'язки (близько 50 \% від бюджету часу трофічних зв'язків). До таких слід відносити живлення омелюха та дятлів. Ці види пов'язані 3 досить обмеженими трофічними ресурсами на липі. Перший вид, хоч i дуже інтенсивно, але живиться виключно ягодами омели, яка відповідно на більшій частині лип у досліджуваній діброві не зустрічається взагалі. Таким чином, більшість зрілої та старої генеративної липи взагалі не має у складі трофоконсортів омелюха. Живлення дятлів на деревах також в основному залежить від наявності старих мертвих гілок, в яких можуть оселитися мурахи. Таким чином, угруповання трофоконсортів липи має нестабільний характер і базується на зв'язках ослаблених екземплярів.

Топічна складова характеризується участю 6 видів птахів птахів (рис. 2, B3). Домінантом у цій частині консортивних зв'язків є також омелюх, субдомінантами блакитна синиця, великий дятел, велика синиця. У консорції зафіксовано 3 види топічних зв'язків птахів. На відміну від молодої генеративної липи, було зафіксовано ще й спів (подача акустичних сигналів). У зимовий час цей вид активності використовується для взаємозв'язку птахів у зграї. Таким чином, липа виявляє більшість топічних зв'язків, характерних для птахів у зимовий період. Враховуючи усе вищенаведене, можна зробити висновок, що липа взимку використовується більше як топічний субстрат, на відміну від літнього періоду.

Весняний період характеризується значною інтенсифікацією консортивних зв'язків птахів з липою. За цією особливістю липа нагадує інші щільнокронні породи.

Весняне угруповання птахів віргінільної липи має досить інтенсивну систему зв'язків. За цим параметром воно нагадує угруповання віргінільного клена. Загальний бюджет часу на один екземпляр автотрофа більший, ніж у ясена, але значно поступається клену (див. табл. 1). Це $є$ наслідком того, що віргінільна липа хоч $\mathrm{i}$ починає вегетацію раніше, ніж дерева середнього та верхнього ярусу, не утворює мікростації, на яку орієнтуються птахи, 3 причини своєї малої чисельності. Більшу частину бюджету часу у птахів цієї консорції займають топічні зв'язки (див. табл. 1). Бюджет маси трофічних зв'язків більший, ніж у клена, майже удвічі (див. табл. 1). За умов майже рівного показника бюджету часу трофічних зв'язків це свідчить про те, що птахи частіше контактують 3 липою, ніж 3 кленом, але надовго на ній для живлення не затримуються. В складі консорції зафіксовано 4 види птахів-консортів. За цим показником липа значно поступається клену польовому.

Трофічна складова зв'язків птахів 3 віргінільною липою весною представлена діяльністю 3 видів птахів (рис. 3, A1, A2). Домінантом за бюджетом часу є білошия мухоловка, за бюджетом маси - велика синиця. Вівчарикковалик за обома показниками сягає рівня субдомінанта.

Співвідношення по концентрах дорівнює I - 0,00 \%, II $81,93 \%$, III - 18,07 \% від DTВ трофічних зв'язків. Активність у третьому концентрі забезпечується споживанням домінантами комах-інсектофагів. Усі трофоконсорти $є$ типовими для нижнього та середнього ярусу липово-ясеневої діброви. Таким чином, липа, як i клен польовий, будує консорцію 3 участю перш за все корінного населення діброви.

Топічна складова системи зв'язків поступається такій в клена та дуба і представлена активністю 4 видів птахів (рис. 3, A3). Домінантом є білошия мухоловка, вільшанка та вівчарик-ковалик - субдомінанти. Липа має найменший показник кількості топічних зв'язків серед усіх щільнокронних порід - усього лише 2. Це свідчить про те, що віргінільна липа весною не надає повноцінного топічного ресурсу для птахів, на відміну від таких же клена та ясена. Це підкреслюється також домінуванням такого виду взаємодій, як спостереження. Домінування білошийої мухоловки можна пояснити тим фактом, що віргінільна липа у досліджуваній діброві розташована поряд з генеративними липами і в даному випадку наявний кондиціонуючий вплив 3 боку консорцій генеративних особин липи. Загалом весняне угруповання віргінільної липи поступається угрупованню клена польового. Липа розвиває своє угруповання на пізнішій віковій стадії, ніж клен.

Консортивне угруповання молодої генеративної липи вже переважає таке ж у клена польового, що підтверджує попередній висновок. У складі консорції цієї вікової групи липи зафіксовано 8 видів птахів-консортів. Загальний бюджет часу майже вдвічі більший, ніж у клена (див. табл. 1). Більшу частину його, на відміну від клена, складають трофічні зв'язки. Бюджет маси втричі більший, ніж у клена (див. табл. 1).

Трофічна складова даної консорції представлена зв'язками 6 видів птахів (рис. $3,51,52$ ). Домінантом у цій частині консортивних зв'язків $є$ велика синиця, субдомінантами за бюджетами часу та маси - зяблик, блакитна синиця, вівчарик-ковалик, білошия мухоловка. Співвідношення по концентрах дорівнює I - 0,40\%, II $88,68 \%$, III - 10,92 \% від DTВ трофічних зв'язків. Активність у першому концентрі має випадковий характер, у третьому забезпечується активністю усіх видів-консортів приблизно однаково і наближається до типової для дуба звичайного. Усі види-трофоконсорти $\epsilon$ корінними для липово-ясеневої діброви. В цілому домінують види нижнього та середнього ярусу, а система зв'язків інтенсивніша і багатша, ніж у клена польового.

Топічна складова представлена активністю також 6 видів птахів (рис. 3, Б3) і в цілому дещо поступається такій у клена польового. Домінантом у цій частині консортивних зв'язків є зяблик. Субдомінантами - білошия мухоловка, вівчарик-ковалик, жовтобровий вівчарик, костогриз. Угруповання топоконсортів має високий рівень вирівняності дольової участі, що свідчить про низький рівень спеціалізації зв'язків. У складі консорції зафіксовано 4 види топічних зв'язків. Жоден 3 консортів не виявив їх повного спектру, що свідчить не на користь топічних ресурсів молодої генеративної липи. Таким чином, консорція молодої генеративної липи весною використовується птахами перш за все як джерело трофічних ресурсів i за топічними показниками поступається іншим деревним породам.

Консортивне угруповання зрілої та старої генеративної липи вирізняється більшою стабільністю та різноманіттям зв'язків, ніж попередні угруповання. Загальний бюджет часу мало поступається такому у зрілого та старого генеративного клена (див. табл. 1). Більшу частину бюджету складають, на відміну від клена, трофічні зв'язки (див. табл. 1). Усього у складі консорції липи у віці $g 2-g 3$ весною виявлено 13 видів птахів.

Трофічна складова характеризується наявністю 7 видів птахів-консортів (рис. $3, B 1, B 2$ ). Домінантом у цій частині зв'язків є блакитна синиця, субдомінантами - велика синиця, повзик, звичайний дятел. Співвідношення по концентрах дорівнює I - 0,93 \%, II - 89,03\%, III - 10,04 \% від DTB трофічних зв'язків. Активність у першому 

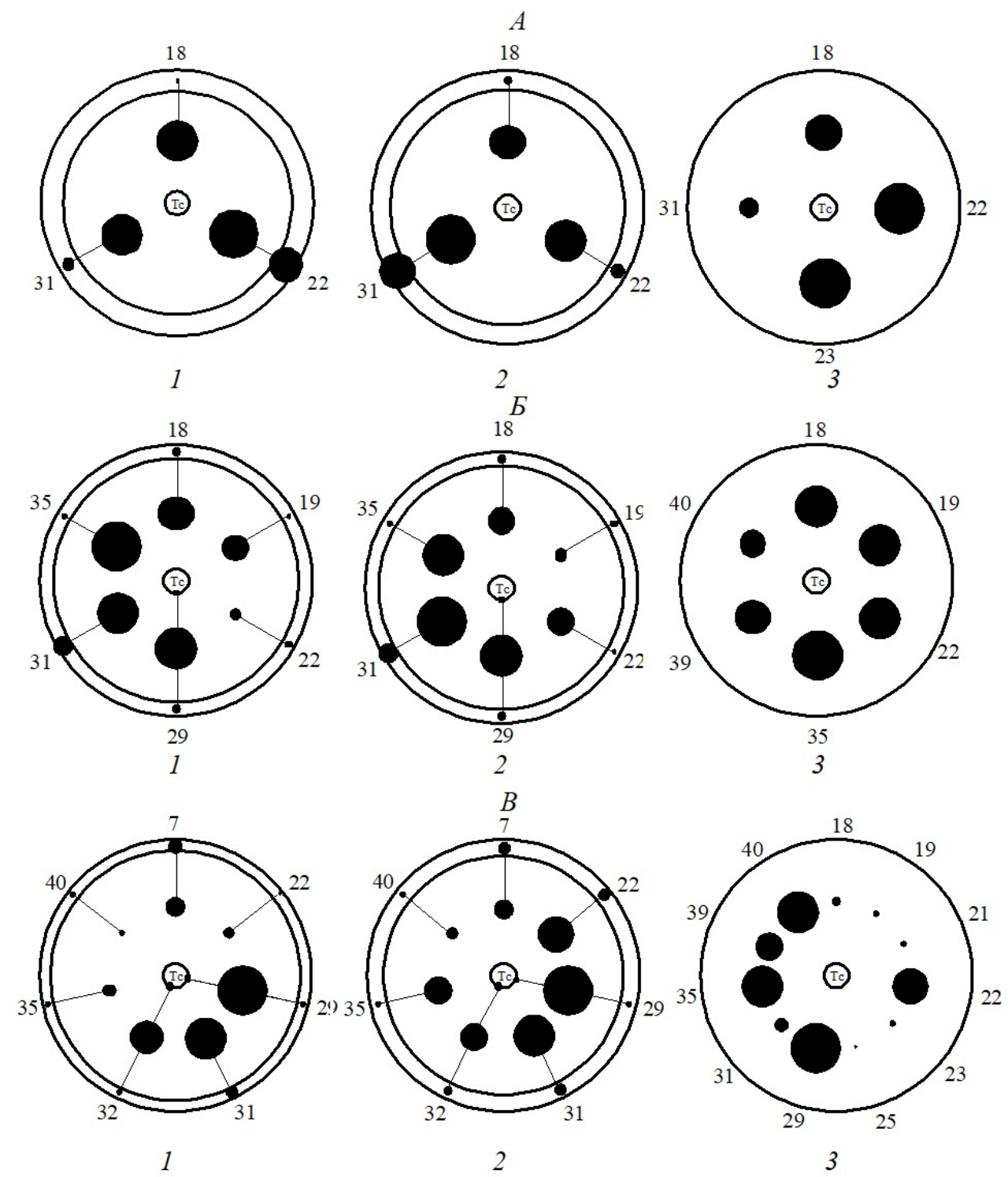

Рис. 3. Схеми консортивних зв'язків птахів з липою серцелистою за бюджетами часу та маси на один екземпляр автотрофа у весняний період:

А - віргінільним $-v$; Б - молодим генеративним $-g 1$; В - зрілим та старим генеративним $-g 2-g 3 ; 1-$ трофічних зв'язків за бюджетом часу; 2 - трофічних зв'язків за бюджетом маси; 3 - топічних зв'язків за бюджетом часу.

Номерами на схемах позначено консортивні зв'язки видів: 1 -Accipiter gentilis; 2 - Buteo buteo; 3 - Cuculus canorus; 4 - Strix aluco; 5 - Jynx torquilla; 6 - Picus canus; 7 - Dendrocopos major; 8 -Dendrocopos medius; 9 - Dendrocopos mino;

10 - Anthus trivialis; 11 - Oriolus oriolus; 12 - Garrulus glandarius; 13 - Corvus cornix; 14 - Bombycilla garrulus;

15 - Sylvia atricapilla; 16 - Sylvia curruca; 17 - Sylvia communis; 18 - Phylloscopus collybita; 19 - Phylloscopus sibilatrix;

20 - Muscicapa striata; 21 - Ficedula hypolenca; 22 -Ficedula albicollis; 23 - Erithacus rubecula; 24 - Luscinia luscinia;

25 - Turdus merula; 26 - Turdus philomelos; 27 - Turdus viscivorus; 28 -Aegithalos caudatus; 29 - Parus caeruleus;

30 - Parus palustris; 31 - Parus major; 32 - Sitta europaea; 33 - Certhia familiaris; 34 - Passer montanus; 35 - Fringilla coelebs; 36 - Chloris chloris; 37 - Carduelis carduelis; 38 - Pyrrhula pyrrhula; 39 - Coccothraustes coccothraustes; 40 - Emberiza citrinella.

концентрі має випадковий характер (шматочки кори попадають разом з комахами), у третьому - забезпечується активністю мухоловки білошийої, великої синиці. Загалом співвідношення по концентрах наближається до типового для дуба звичайного. Усі види трофоконсортів є типовими для діброви. Таким чином, липа, як і клен, будує свій "захист” від фітофагів за допомогою корінних видів діброви.

Топічна складова характеризується участю 11 видів птахів (рис. 3, B3). Таким чином, зріла та стара генеративна липа бере активну участь у формуванні гніздових угруповань птахів і значно переважає у цьому відношенні такого едифікатора, як ясен. Домінантом серед топоконсортів є блакитна синиця, субдомінантами - зяблик, білошия мухоловка, звичайна вівсянка. Пануюча більшість видів $\epsilon$ типовими для нижнього та середнього ярусу діброви. Єдиний вид, який з'являється у складі консорції з узлісся, це вівсянка. Таке явище $є$ наслідком загального підвищення рухливості птахів весною. В консорції було зафіксовано 7 видів топічних зв'язків. За цим показником липа не поступається дубу звичайному і дещо відстає від клена польового. Таким чином, зріла та стара липа також утворює стабільне угруповання топоконсортів.

\section{Висновки}

Враховуючи все вищенаведене, можна зробити такі узагальнення:

1) липа серце листа і дуб звичайний $є$ породами, привабливість яких, на відміну від ясена та клена, значно зростає у весняно-літній період;

2) липа у більшості сезонів року є породою, яка перш за все підтримує систему трофічних зв'язків, а потім топічних; 
3) протягом року липа утворює більш-менш стабільні угруповання на молодій генеративній стадії;

4) враховуючи особливості динаміки консортивних зв'язків птахів, липу можна назвати середовищеутворювачем другого порядку, який $\mathrm{y}$ середньому ярусі взаємодоповнює клен польовий.

\section{References}

Beklemishev, V. N. (1951). O klassifikatsii biogeotsenologicheskih (simfiziologicheskih) svyazey [On the classification of biogeocenotic (symphysiological) connections]. Byulleten MOIP, 55(5), 3-30 (in Russian).

Belgard, A. L. (1960). K teorii strukturyi iskusstvennogo lesnogo soobschestva $\mathrm{v}$ stepi [To the theory of the structure of an artificial forest community in the steppe]. Iskusstvennyie lesa stepnoy zonyi Ukrainyi. Harkov: HGU. 17-32 (in Russian).

Belgard, A. L. (1971). Stepnoe lesovedenie [Steppe forest science]. Moscow, Lesnaya promyishlennost (in Russian).

Chaplygina, A. B., Yuzyk, D. I., Savynska, N. O. (2016a). The robin, Erithacus rubecula (Passeriformes, Turdidae), as a component of autotrophic consortia of forest cenoses, Northeast Ukraine. Vestnik zoologii, 50(4), 369-378.

Chaplygina, A. B., Yuzyk, D. I., Savynska, N. O. (2016b). The robin, Erithacus rubecula (Passeriformes, Turdidae), as a component of heterotrophic consortia of forest cenoses, Northeast Ukraine. part 2. Vestnik zoologii, 50(6), 493-502.

Grigorenko, O. S., Lyindya, A. G. (1977). K ekologii duba chereshchatogo, yasenya obyiknovennogo, klenov ostrolistnogo, polevogo, i lipyi melkolistnoy, proizrastayuschih v dubravah Prisamarya [To the ecology of oak, ash, maples and linden, growing in the oak forests of Prisamarya]. Voprosyi stepnogo lesovedeniya i ohranyi prirodyi, 8, 75-81 (in Russian).

Mazing, V. V. (1966). Konsortsii kak elementyi funktsionalnoy strukturyi biogeotsenozov [Consortia as elements of the functional structure of biogeocenosis]. Trudyi MOIP, 27, $117-126$ (in Russian).

Ponomarenko, O. L. (2005). Dynamika funkcionalnogo skladu ugrupovan ptaxiv u indyvidualnykh konsorciyax lypy sercelystoyi (Tilia cordata) [Dynamics of the birds groups functional composition in individual consortia of linden (Tilia cordata)]. Visnyk Dnipropetrovskogo universy`tetu. Biologiya. Ekologiya, 13(1), 226-231 (in Ukrainian).
Ponomarenko, O. L., Shul'man, M. V. (2019). Vplyv sezonnykh klimatychnykh faktoriv na dynamiku konsortyvnykh zvyazkiv ptaxiv z dubom zvychajnym [Influence of seasonal climatic factors on the dynamics of birds interactions with oaks consortia]. Ecol. Noospher., 30(2), 85-94 (in Ukrainian).

Ponomarenko, O. L. (2017). Pro metodyku doslidzhennya aktyvnosti ptaxiv u derevostani [About a technique of research of activity of birds in a forest]. Vestnik zoologii, 35, 68-72 (in Ukrainian).

Ponomarenko, O. L., Reva, O. A. (2019). Vplyv sezonnykh klimatychnykh faktoriv na dynamiku konsortyvnykh zvyazkiv ptaxiv $\mathrm{z}$ klenom polovym [Influence of seasonal climatic factors on the dynamics of birds interactions with maples consortia]. Pytannya stepovogo lisoznavstva ta lisovoyi rekultyvaciyi zemel, 48, 67-80 (in Ukrainian).

Ramenskiy, L. G. (1952). O nekotoryih printsipialnyih polozheniyah sovremennoy geobotaniki [Some basic principles of modern geobotany]. Bot.zhurnal, 37(2), 181-201 (in Russian).

Smirnova, O. V., Zaugolnova, L. B., Taronova, N. A., Falikov, L. D. (1976). Kriterii vyideleniya vozrastnyih sostoyaniy i osobennosti hoda ontogeneza u rasteniy razlichnyih biomorf [Criteria for the identification of age-related conditions and features of the ontogenesis course in plants of various biomorphs]. Tsenopopulyatsii rasteniy (osnovnyie ponyatiya $\mathrm{i}$ struktura), 1. Moscow, Nauka. $14-43$ (in Russian).

Sukachev, V. N. (1972). Opredelenie ponyatiya "lesnoy biogeotsenoz" ego komponentyi i osnovnyie svoystva [Definition of the term "forest biogeocenosis", its components and basic properties]. Izbrannyie trudyi, 1. Leningrad, Nauka. 329-356 (in Russian).

Tkachenko, M. E. (1955). Obschee lesovodstvo [Common forestry]. Moscow, Leningrad, Goslesbumizdat (in Russian).

Tryfanova, M. V., Kunakh, O. M., Zhukov, O. V. (2015). Doslidzhennya konsortyvnyh zv"yazkiv u biogeocenozax ta oxorona pryrody' [Investigation of consortial connections in biogeocoenoses and nature protection]. Dnipropetrovs`k, DNU (in Ukrainian).

Yuzyk, D. I., Chaplygina, A. B. (2015). Konsorty`vni zv"yazky` pol'ovogo gorobcya (Passer montanus) v umovax lisovy'x cenoziv Pivnichno-Sxidnoyi Ukrayiny' [Consortia interactions of field sparrow (Passer montanus) in conditions of forest cenosis of the North-Eastern Ukraine]. Berkut, 24(2), 142-147 (in Ukrainian). 